\title{
Utilization of Some Tricarboxylic-acid-cycle Intermediates by Mitochondria and Growing Mycelium of Aspergillus terreus
}

\author{
By ANNA NOWAKOWSKA-WASZCZUK \\ Institute of Fermentation and Microbiology, Technical University, \\ Eódż, Poland
}

(Received 17 April 1972; revised 5 March 1973)

\begin{abstract}
SUMMARY
Mitochondria of Aspergillus terreus NRRL 1960 and two mutants, 25/III and $\beta$, were not able to oxidize tricarboxylic-acid-cycle intermediates, either in the presence of ADP or cytochrome $c$, or after disruption of mitochondrial membranes. Reduced pyridine nucleotides, in particular NADH, were the only substrates respired. In the presence of NADH without added ADP the oxygen uptake was from I4 to $55 \mathrm{ng}$-atom oxygen $/ \mathrm{min} / \mathrm{mg}$ protein, while with ADP it was from $2 \mathrm{I}$ to $\mathrm{I} 30 \mathrm{ng}$-atom $\mathrm{O} / \mathrm{min} / \mathrm{mg}$ protein, with respiratory control ratios from $\mathrm{I} \cdot 8$ to $2 \cdot 9$ and $\mathrm{ADP} / \mathrm{O}$ ratios from 0.8 to $\mathrm{I} \cdot 8$. The lowest consumption of oxygen was shown by the mutant $25 /$ III dissimilating nitrate as the source of nitrogen.

The cultures converted malate to itaconate and succinate, fumarate to itaconate and one unknown acid, and pyruvate to all the acids usually produced in glucose media. Succinate, citrate, lactate, propionate and acetate supported growth without acid production.

It is concluded that the synthesis of itaconate in Aspergillus terreus is probably not via the tricarboxylic acid cycle.
\end{abstract}

\section{INTRODUCTION}

Aspergillus terreus NRRL 1960 produces itaconic acid (methylene succinate) with a yield of about $3 \mathrm{~g}$ from $\mathrm{ro} \mathrm{g}$ of glucose. The mutants no. 25/III and $\beta$, resulting from gamma-ray irradiation, are more active itaconic acid producers, giving from 4 to $5 \mathrm{~g}$ itaconic acid from the same amount of glucose (Jakubowska, Nowakowska-Waszczuk, Lasota-Dulkowska, Żakowska \& Sobocka, 1967). Besides itaconate, the strains usually accumulate other branched five-carbon dicarboxylic acids, such as itatartarate ( $\alpha$-hydroxymethylmalate) and its lactone ( $\beta$-hydroxyparaconate), and citraconate (methylmaleate), as well as some acids of the tricarboxylic acid cycle: malic, citric and $\alpha$-oxoglutaric (Jakubowska et al. I967).

In the presence of nitrate as the sole source of nitrogen the parent strain and the mutant $25 /$ III lose the ability to produce itaconic acid and use nitrate as a hydrogen acceptor. Under the same conditions the mutant $\beta$ produces normal amounts of itaconic acid and never dissimilates nitrate (Nowakowska-Waszczuk, 1970, 1971). The mutant 25/III utilizes nitrite as the sole nitrogen source and pre-grown mycelium when incubated in nitrate or nitrite medium has been reported to be able to fix molecular nitrogen. The mutant $\beta$ does not utilize nitrite for growth and mycelium pre-grown in nitrate medium does not fix nitrogen but produces itaconic acid (Nowakowska-Waszczuk, 1972a).

These strains which show different patterns of glucose metabolism have been chosen to 
elucidate the role of the tricarboxylic acid cycle in growth and itaconic acid synthesis by Aspergillus terreus.

The pathway whereby itaconate and related branched five-carbon dicarboxylic acids are formed in Aspergillus terreus is not established. There is evidence for a pathway from the tricarboxylic acid cycle via the decarboxylation of cis-aconitate (Bentley \& Thiessen, I $957 a, b, c)$. Shimi \& Nour El Dein (I962) suggest that cis-aconitate may be generated via a shunt reaction from succinate and acetate, and Lal \& Bhargava (1962) imply that cis-aconitate may be formed by a pathway other than the tricarboxylic acid cycle.

This paper examines the effects of tricarboxylic-acid-cycle intermediates and related metabolites on respiration rates of isolated mitochondria and on the growth and fermentations of cultures of Aspergillus terreus.

\section{METHODS}

Strains and culture media. Aspergillus terreus Thom NRRL 1960 and its two mutants, no. 25/III and $\beta$, were obtained from the culture collection of the Institute of Fermentation and Microbiology, Technical University, tódź, Poland. The strains were grown in static liquid cultures for 62 to $70 \mathrm{~h}$ at $30{ }^{\circ} \mathrm{C}$, in conical flasks containing $50 \mathrm{ml}$ of medium. The culture media were inoculated with spores produced from cultures grown on Czapek-Dox medium supplied with $\mathrm{I} \%$ corn steep liquor or from salted $(3 \% \mathrm{NaCl})$ malt agar. The medium containing ammonia as nitrogen source was composed of: glucose, $50 \mathrm{~g}$; $\left(\mathrm{NH}_{4}\right)_{2} \mathrm{SO}_{4}, 3 \mathrm{~g} ; \mathrm{MgSO}_{4} .7 \mathrm{H}_{2} \mathrm{O}, 0.5 \mathrm{~g} ; \mathrm{KH}_{2} \mathrm{PO}_{4}, 0 . \mathrm{I} \mathrm{g} ; \mathrm{Fe}, 0 . \mathrm{I} \mathrm{mg} ; \mathrm{Cu}, 0.02 \mathrm{mg} ; \mathrm{Zn}, 0.01 \mathrm{mg}$; and distilled water saturated with $\mathrm{CaSO}_{4}$, to I litre; $\mathrm{pH} 5 \cdot 6$. The same medium was applied with tricarboxylic-acid-cycle intermediates as carbon source, instead of glucose.

The culture media with nitrate as source of nitrogen contained: $\mathrm{Ca}\left(\mathrm{NO}_{3}\right)_{2}, 3 \mathrm{~g}$; Fe, I mg; $\mathrm{Cu}, 0 . \mathrm{I} \mathrm{mg}$; $\mathrm{Zn}, 0 . \mathrm{I} \mathrm{mg}$; Mo, $2 \mathrm{mg}$; glucose, magnesium sulphate, potassium phosphate in the same amounts as in the ammonia medium, and distilled water to $\mathrm{I} 1 ; \mathrm{pH} 5.8$ to $6 \cdot 0$.

Preparation of mitochondrial pellet. The mycelium after separation from culture medium was washed with tap water and then distilled water, pressed between layers of absorbent paper, and washed again with a cold solution containing $0.5 \mathrm{M}$-mannitol, $0 . \mathrm{I} \mathrm{M}$-tris- $\mathrm{HCl}$ buffer $\left(\mathrm{pH} 8{ }^{\circ}\right.$ ) and 4 mm-sodium EDTA. The mycelium was then pressed with absorbent paper, cut into small pieces and used for isolation of the mitochondrial fraction. Approximately 18 to $24 \mathrm{~g}$ of mycelium (wet weight) were used for each experiment.

Mitochondria were isolated by the method used for Aspergillus niger (Watson \& Smith, I967, I968), by means of a glass homogenizer. A I $5 \mathrm{~g}$ sample of mycelium (wet weight) was homogenized in $15 \mathrm{ml}$ of extraction medium, which contained $0.5 \mathrm{M}$-mannitol, $0.4 \mathrm{mM}-$ sodium EDTA, Io mM-potassium phosphate buffer $(\mathrm{pH} 7 \cdot 6)$ and $0.2 \%$ bovine serum albumin. All operations were carried out at o to $4{ }^{\circ} \mathrm{C}$.

The homogenate was squeezed through moist nylon cloth and centrifuged at about 800 to $1000 \mathrm{~g}$ for $\mathrm{IO} \mathrm{min}$. The supernatant fluid was decanted and centrifuged at 10000 to $\mathrm{I} 2000 \mathrm{~g}$ for $20 \mathrm{~min}$. The resulting mitochondrial pellet was resuspended in washing solution of the same composition as extraction medium except that the $\mathrm{pH}$ was $7 \cdot 2$, and the above centrifugations were repeated. The mitochondrial fraction was finally resuspended in a small volume of standard reaction medium. In a final volume of $\mathrm{I} \cdot 9 \mathrm{ml}$, the standard reaction medium contained $0.5 \mathrm{M}$-mannitol, $0.2 \mathrm{~mm}$-sodium EDTA, IO mM-potassium phosphate buffer ( $\mathrm{pH}$ from 5.5 to 7.7 ), Io mm-potassium chloride, and $0.2 \%$ bovine serum albumin. It was supplied with substrate, i.e. tricarboxylic-acid-cycle intermediates, $10 \mu \mathrm{mol}$; NADH, NADPH, I $0 \mu \mathrm{mol}$; ADP, $0.2-0.8 \mu \mathrm{mol}$; NAD, NADP, cytochrome $c, 0.2 \mu \mathrm{mol}$. 
Disruption of mitochondrial pellet. Mitochondria resuspended in the reaction medium were disrupted by homogenization with glass beads in the weight ratio $3: 2$ in a glass homogenizer, and after decantation the homogenate was centrifuged at about $1000 \mathrm{~g}$ for Io $\min$.

Measurement of oxygen uptake. A Gilson oxygraph model KM (Middleton, Wisconsin, U.S.A.) with a rapidly oscillating platinum electrode, and a polarizing voltage $0.65 \mathrm{~V}$ were used. The capacity of the reaction vessel was $2 \cdot 2 \mathrm{ml}$. The efficiency of phosphorylation was determined polarographically and expressed as an ADP:oxygen ratio and as a respiratory control ratio, i.e. oxygen uptake with ADP added:oxygen uptake when ADP was depleted (Chance \& Williams, 1956; Hagihara, 1961).

Analyses. Protein was estimated by the biuret method after solubilization with sodium deoxycholate (Jacobs, Jacobs, Sanadi \& Bradley, I956). Pyruvate was determined with 2,4-dinitrophenylhydrazine, $0.1 \%$ dissolved in $2 \mathrm{~N}-\mathrm{HCl}$ (Friedman \& Haugen, 1943). Organic acids accumulated in culture media were evaluated by descending paper chromatography in butanol, formic acid and water $(5: 1: 4$, by vol.), after previous continuous extraction with hot ether for about $30 \mathrm{~h}$. The acid spots were detected with bromphenol blue and with a reagent composed of (i) $\mathrm{KMnO}_{4}, 0.5 \%+\mathrm{Na}_{2} \mathrm{CO}_{3}, \mathrm{I} \%$; (ii) ethanol solutions of bromphenol blue, $0.025 \%+$ bromcresol green, $0.075 \%$. Freshly prepared components (i) and (ii) were mixed in the ratio I: I before use (Paskova \& Munk, I960). Volatile acids were separated by steam distillation of acidified culture medium with $\mathrm{H}_{2} \mathrm{SO}_{4}$ and determined by titration with o.or $\mathrm{N}-\mathrm{NaOH}$. Nucleotides, cytochrome $c$ and tricarboxylic-acidcycle intermediates were purchased from Sigma Chemical Co., London.

\section{RESULTS}

\section{Respiratory capability of mitochondria from Aspergillus terreus}

The ability to respire tricarboxylic-acid-cycle intermediates and the oxidative phosphorylative capacity of mitochondria of Aspergillus terreus were examined by using mycelium actually producing itaconic acid and mycelium without that ability. The mutants $25 / \mathrm{III}$ and $\beta$ growing in the medium containing ammonium as nitrogen source gave mycelia producing acid. The parent strain from the same medium but containing ten times higher iron content, and the mutant $25 /$ III cultivated in the presence of nitrate as source of nitrogen, gave mycelia with no fermentation ability.

In order to isolate tightly coupled mitochondria several precautions were taken: (i) the possible influence of calcium, which was present in large amounts in culture media, was minimized by the addition of sodium EDTA to the mycelial wash solution and to other media used for mitochondrial preparations; (ii) tris- $\mathrm{HCl}$ buffer, $\mathrm{pH} 8.0$, used for the washing of mycelium, and potassium phosphate buffer, $\mathrm{pH} 7 \cdot 8$, used for the homogenization medium, were included to neutralize acids accumulated in mycelia; (iii) bovine serum albumin $(0.2 \%)$ was included in homogenization and further preparative media, to bind endogenous uncoupling agents.

The measure of functional intactness of the mitochondria was the degree of respiratory control (Chance \& Williams, I956).

The mitochondria isolated from mycelium either producing itaconic acid or not producing itaconic acid utilized no oxygen until a substrate was added. However, there was no oxidation of exogenous intermediates of the tricarboxylic acid cycle, supplied in amounts of $5 \mu \mathrm{moles} / \mathrm{ml}$ in the following combinations: pyruvate, pyruvate with malate or succinate; malate, $\alpha$-oxoglutarate, citrate with and without NAD added, then isocitrate and gluta- 


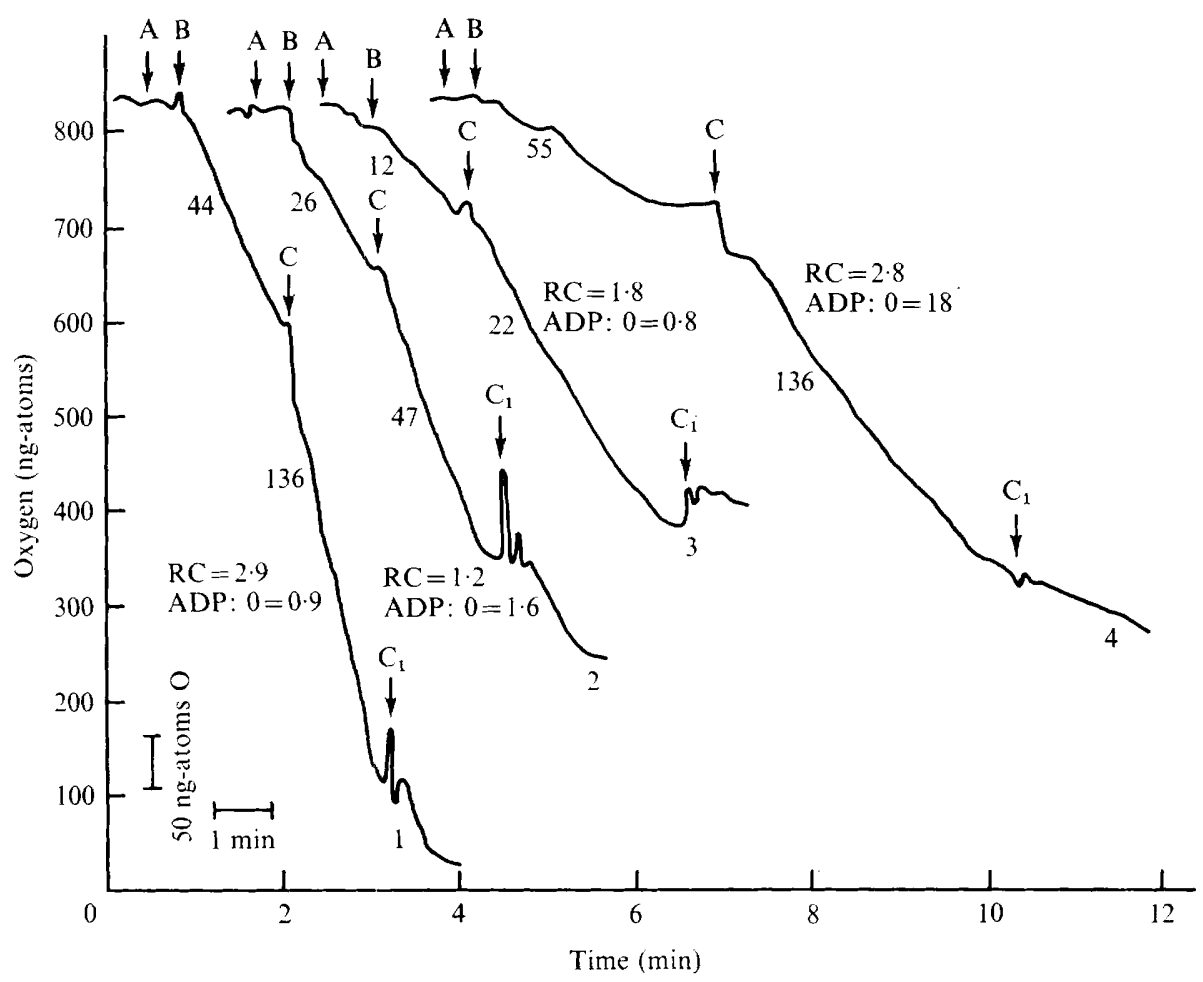

Fig. I. Oxidation of NADH and oxidative phosphorylation in mitochondria from Aspergillus terreus. (I) $A$. terreus NRRL 1960 from ammonia medium; mitochondrial suspension, $2 \cdot 19 \mathrm{mg}$ protein. (2) A. terreus $\beta$ from ammonia medium; mitochondrial suspension, $2 \cdot 74 \mathrm{mg}$ protein. (3) A. terreus $25 / \mathrm{II}$ from nitrate medium; mitochondrial suspension, $3.5 \mathrm{mg}$ protein. (4) A. terreus 25/III from ammonia medium; mitochondrial suspension, $0.5 \mathrm{mg}$ protein. Standard reaction medium in a final volume of $1.9 \mathrm{ml}$ was supplied with: $\mathrm{A}$, mitochondrial suspension; $\mathrm{B}, \mathrm{I} \cdot 0 \mu$ mole $\mathrm{NADH} ; \mathrm{C}$ and $\mathrm{C}_{1}, 0.4 \mu \mathrm{mol}$ ADP. Figures on the traces are the rates of oxygen uptake in ng-atom $/ \mathrm{min} / \mathrm{mg}$ protein.

mate with NAD or NADP. Succinate was assayed alone and with glutamate because the latter stimulated succinate oxidation in Aspergillus niger mitochondria (Higgins \& Friend, 1968). Neither ADP at $0.2,0.4$ and $0.8 \mu \mathrm{mol}$, nor cytochrome $c$ had any effect on oxidation of tricarboxylic-acid-cycle intermediates. $\beta$-Hydroxybutyrate and itaconate gave the same negative results.

The possibility of mitochondrial permeability barriers to these substrates was checked by disrupting washed mitochondria by homogenization with glass beads. However, these fragments did not respire tricarboxylic-acid-cycle intermediates.

NADH and NADPH were the only substrates oxidized by mitochondria of all Aspergillus terreus strains tested. The degree of respiratory control showed that the mitochondria coupled oxidation of NADH to phosphorylation of ADP. In the presence of NADH they exhibited high rates of oxygen uptake (Fig. I). The oxidation was completely inhibited by $0 \cdot 2 \mathrm{~mm}-\mathrm{KCN}$.

All strains exhibited the same pattern of respiration, i.e. no strain respired tricarboxylicacid-cycle intermediates and all respired reduced nicotinamide dinucleotides regardless of the metabolic pathway actually operating during the growth of mycelium on glucose medium. Mitochondria of the parent strain not producing itaconic acid, i.e. completely 
Table I. The effect of cytochrome $c$ on oxidation of $N A D H$ in mitochondria from Aspergillus terreus

\begin{tabular}{|c|c|c|}
\hline Strain & Standard system of assays* & $\begin{array}{l}\text { Oxygen } \\
\text { (ng-atom/ } \\
\text { min/mg } \\
\text { protein) }\end{array}$ \\
\hline$\beta$ & $\begin{array}{l}\text { Mitochondria, } 2.7 \mathrm{mg} \text { protein } \\
\text { Mitochondria, } 2.7 \mathrm{mg} \text { protein }+ \text { cytochrome } c \\
\text { Mitochondrial homogenate, } \mathrm{I} .88 \mathrm{mg} \text { protein } \\
\text { Mitochondrial homogenate, } 1.88 \mathrm{mg} \text { protein }+ \text { cytochrome } c\end{array}$ & $\begin{array}{l}26 \\
36 \\
22 \\
64\end{array}$ \\
\hline $25 / \mathrm{III}$ & $\begin{array}{l}\text { Mitochondria, } 1.0 \mathrm{mg} \text { protein } \\
\text { Mitochondria, } 1.0 \mathrm{mg} \text { protein }+ \text { cytochrome } c\end{array}$ & $\begin{array}{l}63 \\
63\end{array}$ \\
\hline NRRL 1960 & $\begin{array}{l}\text { Mitochondria, } 2.19 \mathrm{mg} \text { protein } \\
\text { Mitochondria, } 2.19 \mathrm{mg} \text { protein }+ \text { cytochrome } c\end{array}$ & $\begin{array}{l}67 \\
67\end{array}$ \\
\hline
\end{tabular}

* Standard assay system contained in $1.9 \mathrm{ml}: \mathrm{NADH}, 1 \mu$ mole; cytochrome $c, 0.2 \mu$ mole; $\mathrm{MgCl}_{2}$, $0.02 \mu$ mole; $\mathrm{pH} 7 \cdot 0$.

Table 2. Oxidation of nicotinamide nucleotides by mitochondria from Aspergillus terreus

\begin{tabular}{|c|c|c|c|c|c|c|}
\hline Strain & $\begin{array}{l}\text { Nitrogen } \\
\text { source }\end{array}$ & $\begin{array}{c}\text { Protein } \\
\text { (mg/sample) }\end{array}$ & $\begin{array}{l}\text { Nicotinamide } \\
\text { nucleotides }\end{array}$ & $\begin{array}{c}\text { Oxygen } \\
\text { (ng-atom/ } \\
\text { min/mg } \\
\text { protein) }\end{array}$ & $\begin{array}{l}\text { ADP:O } \\
\text { ratio }\end{array}$ & $\begin{array}{l}\text { Respiratory } \\
\text { control } \\
\text { ratio }\end{array}$ \\
\hline$\beta$ & $\mathrm{NH}^{+}$ & $2 \cdot 74$ & $\begin{array}{l}\text { NADH } \\
\text { NADPH }\end{array}$ & $\begin{array}{l}47 \cdot 2 \\
12 \cdot 0\end{array}$ & $\begin{array}{l}I \cdot 6 \\
I \cdot 6\end{array}$ & $\begin{array}{l}I \cdot 6 \\
I \cdot 3\end{array}$ \\
\hline \multirow[t]{2}{*}{$25 / \mathrm{III}$} & $\mathrm{NH}^{+}$ & 0.50 & $\begin{array}{l}\text { NADH } \\
\text { NADPH }\end{array}$ & $\begin{array}{r}130 \cdot 0 \\
2 \cdot 0\end{array}$ & $1 \cdot 8$ & $\begin{array}{l}2 \cdot 8 \\
-\end{array}$ \\
\hline & $\mathrm{NO}_{3}^{-}$ & 3.50 & $\begin{array}{l}\text { NADH } \\
\text { NADPH }\end{array}$ & $\begin{array}{r}2 \mathrm{I} \cdot 0 \\
9 \cdot 8\end{array}$ & $\begin{array}{l}\mathrm{I} \cdot 7 \\
0.8\end{array}$ & $\begin{array}{l}\mathrm{I} \cdot 8 \\
\mathrm{I} \cdot 6\end{array}$ \\
\hline NRRL 1960 & $\mathrm{NH}_{4}^{+}$ & $2 \cdot 19$ & $\begin{array}{l}\text { NADH } \\
\text { NADPH }\end{array}$ & $\begin{array}{r}120 \cdot 0 \\
28 \cdot 0\end{array}$ & $\begin{array}{l}0.9 \\
0.9\end{array}$ & $\begin{array}{l}2 \cdot 8 \\
1 \cdot 2\end{array}$ \\
\hline
\end{tabular}

Standard assay system contained in $\mathrm{I} \cdot 9 \mathrm{ml}$ : NADH or NADPH, $1 \mu$ mole; ADP, $0.4 \mu$ mole; $\mathrm{MgCl}_{2}$, $0.2 \mu$ mole; $\mathrm{pH} 6.8$.

oxidizing glucose during $68 \mathrm{~h}$ of cultivation in ammonia medium, and mitochondria of the mutant 25/III synthesizing itaconic acid under similar conditions, showed similar rates of oxygen uptake. Mitochondria of the latter strain from mycelium incubated in nitrate medium oxidized NADH more slowly, indicating that the pathway of electron transfer to oxygen is less prominent in these conditions.

The mitochondria from the mutant $\beta$ proved to have a lower respiration rate. This mutant was the best itaconic acid producer, and always showed restricted growth and gave very thin and fragile mycelium. The methods used for isolation of the mitochondrial fraction seemed to damage the mitochondria more, despite reducing the homogenization time from $\mathrm{Io}$ to $5 \mathrm{~min}$, as shown by the fact that the respiration was significantly increased by an addition of cytochrome $c$, especially after disruption of mitochondrial membranes (Table I).

The rapid oxidation of reduced adenine nicotinamide dinucleotide indicated that mitochondrial membranes were readily permeable to it. This was confirmed since oxidation of added NADH was not augmented after disruption of mitochondria. NADH was oxidized more readily than NADPH (Table 2). 


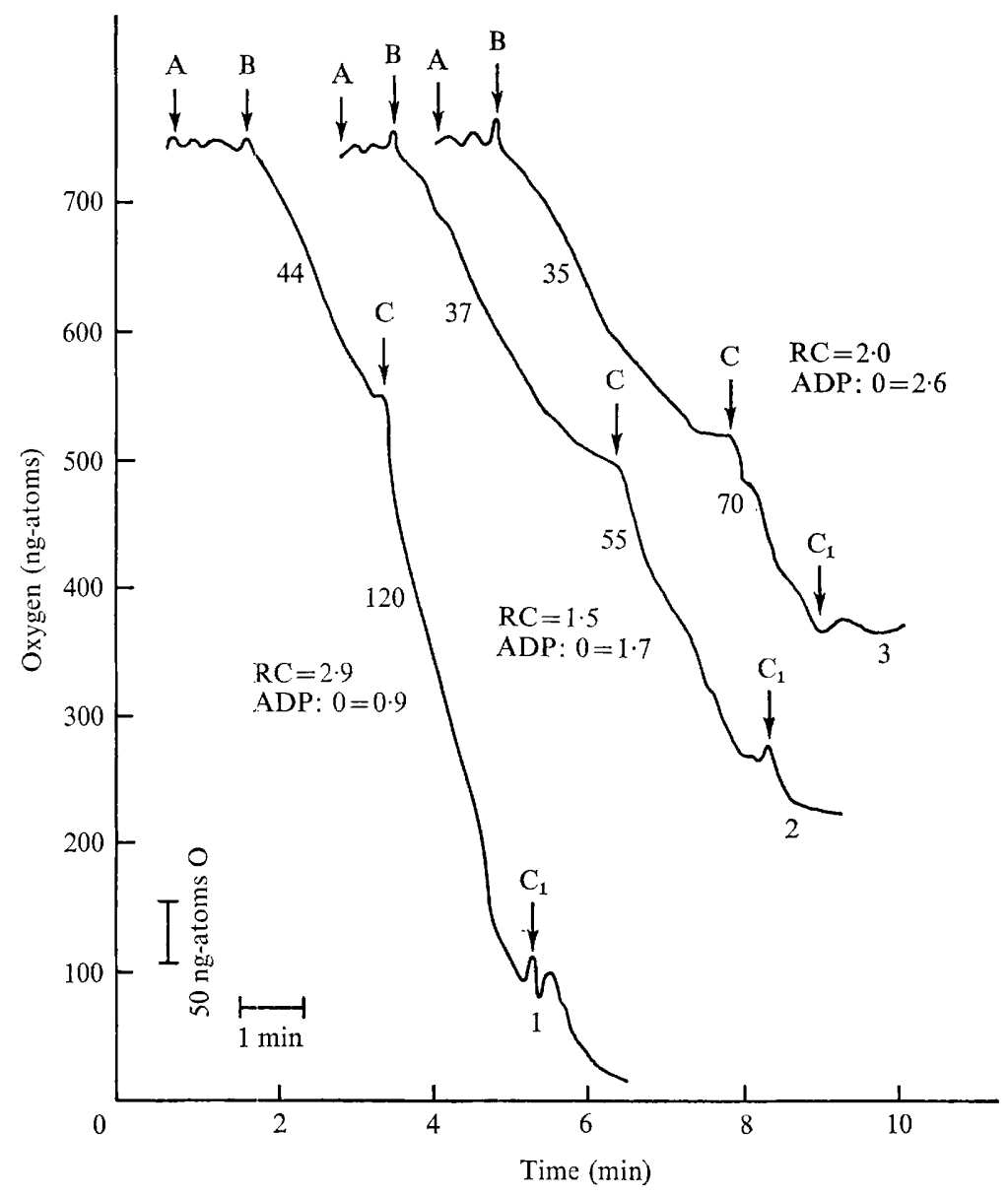

Fig. 2. The effect of magnesium on oxidation of NADH and oxidative phosphorylation in mitochondria from Aspergillus terreus NRRL 1960. (1) No added $\mathrm{MgCl}_{2}$; (2) $\mathrm{MgCl}_{2}, 2 \mu \mathrm{mol}$; (3) $\mathrm{MgCl}_{2}, 5 \mu \mathrm{mol}$. The standard reaction medium of final volume of $\mathrm{I} \cdot 9 \mathrm{ml}$ was supplied with: A, mitochondrial suspension, $2.19 \mathrm{mg}$ protein; $\mathrm{B}, 1.0 \mu$ mole NADH; C, $0.4 \mu$ mole ADP. Figures on the traces are the rates of oxygen uptake in $\mathrm{ng}$-atoms $/ \mathrm{min} / \mathrm{mg}$ protein.

Oxidative phosphorylation with NADH was dependent upon the concentration of $\mathrm{Mg}^{2+}$ added to the reaction medium. If $\mathrm{Mg}^{2+}$ was omitted, added ADP gave an intense oxidation coupled to phosphorylation. With added $\mathrm{Mg}^{2+}$ this effect was shorter and dependent on the concentration of added magnesium. At $5 \mu \mathrm{mol} \mathrm{Mg}^{2+}$ the second addition of ADP appeared harmful and inhibited oxygen uptake (Fig. 2). The respiration rate without added ADP was also better in the absence of magnesium than in its presence. Lowering the oxygen uptake by magnesium markedly influenced the ADP:O ratio. The effect of magnesium is difficult to compare with oxidation of other substrates observed in other fungi. In yeast mitochondria $\mathrm{Mg}^{2+}$ inhibited phosphorylation with succinate and citrate, but with NADH it had no effect (Subik \& Kolarov, I970). In Aspergillus niger $5 \mu \mathrm{mol}-\mathrm{Mg}^{2+}$ lowered the respiratory control with succinate but not with $\alpha$-oxoglutarate (Watson \& Smith, 1967). The inhibition of NADH oxidase by divalent cations, including magnesium, was observed in extracts from Bacillus cereus. This effect is believed to be due to the removal of an essen- 
Table 3. The effect of $p H$ on respiratory activity with $N A D H$ in mitochondria of Aspergillus terreus $25 / \mathrm{II}$, cultivated in ammonia medium

\begin{tabular}{ccr}
$\mathrm{pH}$ & \multicolumn{2}{c}{$\begin{array}{c}\text { Oxygen } \\
\text { (ng-atom/min/mg protein) }\end{array}$} \\
$5.5-6 \cdot 0$ & Without ADP & With ADP \\
6.6 & $43 \cdot 5-50 \cdot 6$ & $50 \cdot 0-54 \cdot 0$ \\
$7 \cdot 0$ & $40 \cdot 0-67 \cdot 0$ & $70 \cdot 0-77 \cdot 0$ \\
$7 \cdot 7$ & $60 \cdot 0-66 \cdot 0$ & $72 \cdot 0-77 \cdot 0$ \\
& $42 \cdot 0-43 \cdot 0$ & $63 \cdot 0-66 \cdot 0$
\end{tabular}

Standard assay system contained in $\mathrm{I} \cdot 9 \mathrm{ml}$ : NADH, I $\mu$ mole; ADP, $0.4 \mu$ mole; $\mathrm{MgCl}_{2}, 0.2 \mu$ mole; protein I $\circ \mathrm{omg}$.

Table 4. Respiratory activity of crude extracts and soluble fractions from Aspergillus terreus $\beta$, cultivated for $48 h$

$\begin{array}{llcc}\text { Preparation } & \text { Substrate } 10 \mu \text { moles } & \text { A } & \begin{array}{c}\text { Oxygen } \\ \text { (ng-atom/min } / \mathrm{mg} \\ \text { protein)* }\end{array} \\ \text { Crude extract } & \text { None } & 50-130 & 50-125 \\ & \text { Malate } & 45-85 & 50-85 \\ \text { Syruvate } & \text { Succinate } & 60-75 & 60-85 \\ \text { Soluble fraction } & \text { None } & 60-75 & 50-60 \\ & & 300-680 & 100-130\end{array}$

Crude extract from ammonia medium, $0.86 \mathrm{mg}$ protein; crude extract from nitrate medium, $\mathrm{I} .02 \mathrm{mg}$ protein; soluble fraction from ammonia medium, $0.51 \mathrm{mg}$ protein; soluble fraction from nitrate medium, $0.54 \mathrm{mg}$ protein. Standard assay system: final volume, $1 \cdot 9 \mathrm{ml} ; \mathrm{pH}, 6.8$.

* A, cultivated in ammonia medium; B, cultivated in nitrate medium.

Table 5. Growth of two strains of Aspergillus terreus on pyruvate medium $(\mathrm{I} 7.4$ mmoles of pyruvate $/ 100 \mathrm{ml})$

\begin{tabular}{|c|c|c|c|c|}
\hline \multirow[b]{2}{*}{ Days } & \multicolumn{2}{|c|}{$\begin{array}{l}\text { Mycelial dry weight } \\
(\mathrm{mg} / \mathrm{I} \text { oo ml })\end{array}$} & \multicolumn{2}{|c|}{$\begin{array}{l}\text { Pyruvate utilization } \\
\text { (mmoles/100 ml) }\end{array}$} \\
\hline & $25 / \mathrm{III}$ & $\beta$ & $25 / \mathrm{III}$ & $\beta$ \\
\hline I & 100 & 98 & $2 \cdot 7$ & $I \cdot 4$ \\
\hline 2 & I 54 & 138 & 5.0 & $4 \cdot 2$ \\
\hline 3 & I95 & I 87 & $7 \cdot 8$ & $7 \cdot 8$ \\
\hline 4 & 200 & I 85 & $8 \cdot 7$ & 8.0 \\
\hline 5 & 200 & I 87 & $8 \cdot 7$ & 8.0 \\
\hline
\end{tabular}

tial flavine cofactor, since the addition of riboflavine and flavine mononucleotides can restore NADH oxidase activity (Thompson \& Nakata, 197I).

Only the first addition of ADP significantly stimulated respiration with NADH in the mitochondrial preparations of Aspergillus terreus. Together with the low ADP:O ratios and high respiratory rates without ADP, this suggests the existence of an active adenosine triphosphatase (ATPase).

The maximum respiratory control ratio for NADH oxidation was 2.9 . In Aspergillus niger mitochondria (Watson \& Smith, 1967), in Aspergillus oryzae (Watson, Paton \& Smith, I969) and Neurospora crassa (Hall \& Greenawalt, I967; Weiss, Jagow, Klingenberg \& Buchner, 1970) maximum respiratory control ratios were $2 \cdot 5, \mathrm{I} \cdot 8$ and $2 \cdot 3$, respectively. 
Table 6. Growth of Aspergillus terreus on the media with acids converted to other acids

\begin{tabular}{llccc}
\multirow{2}{*}{ Strain } & Substrate & $\overbrace{3 \cdot 0 \text { to } 4 \cdot 0}$ & $\begin{array}{c}\text { Mycelial dry weight after } 3 \text { days } \\
(\mathrm{mg} / \mathrm{l} 00 \mathrm{ml}) \text { for initial } \mathrm{pH} \text { of : }\end{array}$ \\
$25 / \mathrm{III}$ & Glucose & 370 & 550 & $6 \cdot 0$ to $7 \cdot 0$ \\
& Malate & 360 & 310 & 370 \\
$\beta$ & Fumarate & 497 & 320 & 140 \\
& Glucose & 330 & 380 & 125 \\
& Malate & 300 & 240 & 400 \\
& Fumarate & 370 & 270 & 120
\end{tabular}

Table 7. Growth of two strains of Aspergillus terreus on the media containing acids not converted to other acids (results after 4 days)

$\begin{array}{lccc}\text { Substrate } & \text { Optimum pH } & \overbrace{25 / \mathrm{III}} & \beta \\ \text { Citrate } & 4 \cdot 5-5 \cdot 0 & 510 & 340 \\ \text { Succinate } & 3 \cdot 0-4 \cdot 0 & 320 & 320 \\ \text { Lactate } & 4 \cdot 5 & 396 & 300 \\ \text { Propionate* } & 6 \cdot 0 & 190 & \text { I } 60 \\ \text { Acetate } & 6.5 & 210 & 240\end{array}$

* Growth delayed by 3 days, results after 5 days.

The optimum $\mathrm{pH}$ range for oxidation of $\mathrm{NADH}$ was near to $7 \cdot 0$. The lower $\mathrm{pH}$ values, 6.0 and 5.5, caused uncoupling (Table 3). This is in agreement with Aspergillus niger mitochondria which exhibited the highest respiratory rates within similar $\mathrm{pH}$ ranges (Watson \& Smith, I967).

The crude extracts and soluble fractions showed a higher endogenous respiration rate than washed mitochondria. However, neither pyruvate nor malate and succinate enhanced the respiratory rates (Table 4). Endogenous respiration rates of soluble fractions were higher than those in crude extracts. Those obtained from organisms grown in ammonia medium gave much higher rates than those from nitrate medium.

\section{Metabolism of some tricarboxylic-acid-cycle intermediates and other acids by growing mycelium}

Mycelium of mutants $25 / \mathrm{III}$ and $\beta$ was grown in the presence of pyruvate, malate, fumarate, succinate, citrate, lactate, propionate and acetate, as the only carbon source. The acids were tested at a concentration of $2 \%$ and at $\mathrm{pH}$ values from $2 \cdot 5$ to $7 \cdot 0$. Cultures with $2 \%$ glucose and similar $\mathrm{pH}$ levels, acted as controls. Mycelial dry weight, $\mathrm{pH}$ changes and the presence of organic acids were examined.

The utilization of acids was strongly dependent on $\mathrm{pH}$. On malate, fumarate and succinate optimum $\mathrm{pH}$ for utilization by both strains was within the range $3 \cdot 0$ to 4.5 , on pyruvate and lactate 4.0 to 4.5 , on citrate 4.5 to 5.5 , and on propionate and acetate about 6.0. On all acid media except for propionate and acetate the poorest growth of both strains was from $\mathrm{pH} 6 \cdot 0$ to $7 \cdot 0$. Citrate did not support growth at $\mathrm{pH} 2 \cdot 0$ or $7 \cdot 0$.

The results summarized in Tables 5 and 6 reveal that pyruvate, malate and fumarate were 
converted to other organic acids in amounts that were easily detectable on chromatograms of culture filtrates. Malate was converted to the acids whose $R_{F}$ values corresponded to itaconate and succinate; fumarate was converted to itaconate and one unknown acid with $R_{F}$ value of 0.57 , that gave a dark pink spot after treatment with the $\mathrm{KMnO}_{4}$-bromphenol blue-bromcresol green reagent.

In the medium with pyruvate the same acids were produced as in glucose medium, i.e. itaconic, itatartaric acid-lactone, citramalic or $\alpha$-oxoglutaric, citric and malic, plus hydroxyacetic, fumaric or mesaconic and one acid giving the long intense spot between itatartarate and malate that disappeared after the passage of the culture filtrates through a cationic exchanger. In pyruvate medium both strains produced volatile acids in amounts equivalent to about $100 \mu$ moles of acetate/100 $\mathrm{ml}$.

In spite of abundant acid production, growth of the mutants was restricted and about $50 \%$ of pyruvate was not utilized. This inhibition was probably the result of the simultaneous presence of pyruvate and some products of its metabolism. To prevent such an effect pyruvate was replaced by lactate as the nearest homologue. However, lactate was not converted to other acids. The lack of acid production from lactate excluded the conversion via pyruvate but suggested the pathway via acrylate and propionate, the more so as both strains were able to grow on propionate as the sole source of carbon (Table 7).

Propionate as well as citrate, succinate, lactate and acetate supported growth without accumulation of other acids in culture media (Table 7 ).

\section{DISCUSSION}

The results provide no evidence for active tricarboxylic-acid-cycle enzymes in Aspergillus terreus NRRL I 960 and its two mutants, in mycelium either producing or not producing itaconic acid. If the cycle were operating, the parent strain not producing itaconic acid in ammonia medium should demonstrate the activity of all enzymes of the cycle, while the strains actually producing itaconic acid should show active malic and succinic dehydrogenases. However, this did not occur.

The results with growing mycelium suggest that pyruvate, fumarate and malate, while being converted to other organic acids, are not metabolized via citrate and succinate, and that there is a mutual conversion of malate and fumarate but not of fumarate and succinate. Bentley \& Thiessen (1957 $a, b, c)$ have suggested that citrate is the penultimate precursor of itaconate in Aspergillus terreus. However, there is evidence that citrate is not the precursor of cis-aconitate, because it gives a poor yield of itaconate in experiments with intact mycelium and extracts (Eimhjellen \& Larsen, 1955; Bentley \& Thiessen, 1957 b), and experiments with aconitase inhibitors have not confirmed the role of citrate in the synthesis of itaconate in Aspergillus terreus (Shimi \& Nour El Dein, 1962; Bentley \& Thiessen, $1957 c$ ).

If pyruvate is not being oxidized in the tricarboxylic acid cycle it must be metabolized to itaconic acid by another pathway. Phosphoroclastic cleavage of pyruvate to acetylphosphate and formate or acetylphosphate and carbon dioxide and hydrogen has recently been demonstrated in cell-free extracts of Aspergillus terreus (Nowakowska-Waszczuk, I972b), and could provide acetate or acetyl coenzyme $A$ as an intermediate in itaconic acid synthesis. Shimi \& Nour El Dein (I962), using tricarboxylic-acid-cycle inhibitors, suggested a condensation of three acetate molecules into 1,2,3-tricarboxypropane, involving a methyl condensation of two acetyl molecules with NAD as electron acceptor, to form a fourcarbon compound, probably succinate, and then the addition of the third acetyl group to I,2,3-tricarboxypropane (3-carboxyglutarate). 
The formation of itaconate via such a sequence is in an accord with the results of Bentley \& Thiessen (I957a, b, c) and Corzo \& Tatum (1953), and is consistent with: (i) the distribution of isotopes in $\mathrm{C}_{1}, \mathrm{C}_{2}$, and $\mathrm{C}_{3}$ carbon atoms of itaconate during growth of Aspergillus terreus with $\left[\mathrm{I}^{14} \mathrm{C}\right]$ glucose (Bentley \& Thiessen, $1957 a$ ); (ii) incorporation of labelled $\left[1,2-{ }^{14} \mathrm{C}\right]$ acetate and the carbon skeleton of succinate into itaconate (Bentley \& Thiessen, I957a; Corzo \& Tatum, 1953); (iii) localization of most of the radioactivity from $\left[2-{ }^{14} \mathrm{C}\right]$ acetate into $\mathrm{C}_{5}$ of itaconate during short-time cultivation of pre-grown mycelium with labelled acetate (Corzo \& Tatum, I953); and (iv) the active decarboxylation of cis-aconitate by extracts of Aspergillus terreus (Bentley \& Thiessen, $1957 b, c$ ).

The studies on the respiratory capability of mitochondria from Aspergillus terreus were carried out in the Department of Applied Microbiology, University of Strathclyde, Royal College, Glasgow. I am very grateful to Professor E. O. Morris and Dr J. E. Smith for permission to do the experiments there, and for their kindness. Thanks are extended to all the staff of Professor E. O. Morris.

\section{REFERENCES}

Bentley, R. \& ThIEssen, C. P. (1957a). Biosynthesis of itaconic acid in Aspergillus terreus. I. Trace studies with labelled $\mathrm{C}^{14}$-substrate. Journal of Biological Chemistry 226, 673-687.

Bentley, R. \& Thiessen, C. P. (I957b). Biosynthesis of itaconic acid in Aspergillus terreus. II. Early stages in glucose dissimilation and the role of citrate. Journal of Biological Chemistry 226, 689-70I.

BentLey, R. \& Thiessen, C. P. (1957c). Biosynthesis of itaconic acid in Aspergillus terreus. III. The properties and reaction mechanism of cis-aconitic acid decarboxylase. Journal of Biological Chemistry 226, 703-720.

ChancE, B. \& Williams, G. R. (1956). The respiratory chain and oxidative phosphorylation. Advances in Enzymology 17, 65-1 34 .

Corzo, R. H. \& Tatum, E. L. (1953). Biosynthesis of itaconic acid. Federation Proceedings 12, 470.

Eimhjellen, K. \& Larsen, H. (I955). The mechanism of itaconic acid formation by Aspergillus terreus. II. The effect of substrate and inhibitors. Biochemical Journal 60, 139-I 47.

Friedman, T. E. \& Haugen, G. E. (1943). The estimation of ketoacids in blood and urine. Journal of Biological Chemistry I47, 41 5-442.

HAGIHARA, B. (196I). Technique for the application of polarography to mitochondrial respiration. Biochimica et biophysica acta 46, 134-141.

HaLL, D. O. \& GREENAwALT, J. W. (I967). The preparation and biochemical properties of mitochondria from Neurospora crassa. Journal of General Microbiology 48, 419-430.

Higgins, E. S. \& Friend, H. W. (1968). Comparative mitochondrial function in two strains of Aspergillus niger. Canadian Journal of Biochemistry 46, I5 I 5-1525.

JACOBS, E., JACOBS, M., SANADI, D. R. \& BRADLEY, L. B. (1956). Uncoupling of oxidative phosphorylation by cadmium ions. Journal of Biological Chemistry 223, I $47-156$.

Jakubowska, J., Nowakowska-Waszczuk, A., Lasota-Dulkowska, E., Żakowska, Z. \& Sobocka, B. (1967). Studies on itaconic and itatartatic acid production by gamma isolates of Aspergillus terreus. Acta microbiologica polonica 16, 227-236.

LAL, M. \& Bhargava, P. M. (1962). Reversal by pyruvate of fluoride inhibition in Aspergillus terreus. Biochimica et biophysica acta 58, 628-630.

NowakowsKa-WASZCZUK, A. (1970). Assimilatory and dissimilatory utilization of nitrate by Aspergillus terreus mutants. Acta microbiologica polonica B 2, 83-94.

NowaKowsKA-WASZCZUK, A. (197I). A response of Aspergillus terreus mutants to nitrite. Acta microbiologica polonica $\mathrm{B} 3, \mathrm{I} 3^{-22}$.

Nowakowska-WaSzCZUK, A. (1972a). Nitrogen fixation by Aspergillus terreus. Acta microbiologica polonica B 4, 75-82.

NowAKOWSKA-WASZCZUK, A. (1972 b). Metabolism of glucose in Aspergillus terreus, itaconic acid producer. Zeszyty Naukowe Politechniki Éódzkiej, Chemia Spożywcza, Nr 22, 5-89 (Habilitation thesis, in Polish).

Paskova, J. \& MUNK, V. (I960). A combined detecting reagent for the identification of organic acids on paper chromatograms. Journal of Chromatography 4, 24I-246. 
Shimi, I. R. \& Nour El Dein, M. S. (1962). Biosynthesis of itaconic acid by Aspergillus terreus. Archiv für Mikrobiologie 44, I8I-I88.

SUbiK, J. \& Kolarov, J. (1970). Metabolism of calcium and effect of divalent cations on respiratory activity of yeast mitochondria. Folia microbiologica (Praha) 14, 448-457.

Thompson, E. D. \& NAKATA, H. M. (1971). Reduction of activity of reduced nicotinamide dinucleotide oxidase by divalent cations in cell-free extracts of Bacillus cereus T. Journal of Bacteriology 105, 494-497.

Watson, K., Paton, W. \& SMith, J. E. (1969). Oxidative phosphorylation and respiratory control in mitochondria from Aspergillus oryzae. Canadian Journal of Microbiology 15, 975-977.

WAtson, K. \& SMITH, J. E. (1967). Oxidative phosphorylation and respiratory control in mitochondria from Aspergillus niger. Biochemical Journal 104, 332-339.

Watson, K. \& Sмітн, J. E. (1968). Respiratory components of Aspergillus niger mitochondria. Journal of Bacteriology 96, I 546-1550.

Weiss, H., JAGOw, B., Klingenberg, M. \& Buchner, T. (1970). Characterization of Neurospora crassa mitochondria prepared with a grind-mill. European Journal of Biochemistry 14, 75-82. 